\title{
The Violations of Cooperative Principle as The Creativity of Humour in Banjar Madihin Art
}

\author{
Siti Faridah", $^{1}$ Rustono $^{2}$, Agus Nuryatin ${ }^{3}$, Hari Bakti Mardikantoro ${ }^{4}$ \\ ${ }_{1,2,3,4}$ Graduate School,Univesitas Negeri Semarang, Indonesia \\ ${ }^{1}$ Corresponding email : faridah@gmail.com
}

\begin{abstract}
Madihin art is one of the oral literatures in Banjarmasin, Indonesia. It is performed alongside humour that can be used as a way of communication. The purpose of this study was to find out the violations of the cooperative principle in Banjar madihin art by identifying the violations of conversational maxims. It employed descriptive qualitative method. Meanwhile, the research data consisted of ten videos of Banjar madihin art performances chosen randomly either the date or location of performances and downloaded from Youtube from February 2017 until December 2017. The data collection of those videos was done by the methods of recording, relating and note-taking. Further, the collected data were analysed using normative method. The results showed that the violations of cooperative principle, namely 6 violations of the maxim of quantity or $17 \%, 8$ maxim of quality violations or $23 \%, 11$ violations of the maxim of relevance or $31 \%$ and 10 violations of the maxim of manner or $29 \%$. It showed that the highest rank of the maxim violation was the maxim of relevance violations. Moreover, there were found irrelevant, unclear, disorderly and ambiguous speeches in accordance with the matter discussed. They are intended a means of creativity of humour.
\end{abstract}

Keywords: maxims of cooperative principle, madihin art, humour creativity.

\section{Introduction}

One of the well-known oral literatures of Banjar region in South Kalimantan is madihin art. It is a Banjar oral literature art which is presented in the form of performance (Yulianto, 2015). Madihin comes from the Arabic word 'madah' which means 'advice', but it can also mean 'praise'. This art then becomes a genre of poetry from the Banjar tribe and it only exists among the Banjar tribe in South Kalimantan. Madihin began to be known since 1800 invented by the Banjar community and continues to grow until now that people can still enjoy it (Leha, 2018). This art is an entertainment for the whole community (Rafiek, 2016). It is performed by the artists of madihan called 'pemadihinan' accompanied by a traditional musical instrument called as 'tarbang' or 'Rebana' (tambourine). Over time, the function of madihin art changes into the entertainment for people at certain times such as entertainment fillers after harvest, marriage, circumcision and as a means to criticize the government, media information, socialization government programs, education media, and da'wah (the proselytizing or preaching of Islam) media. In addition, the performance of madihin art is not only aimed at serving entertain the community but also a form to preserve local culture Banjar (Faridah, 2017).
Apparently, there found humour aspects in the speeches of Banjar madihin art. Humour is any form of stimulation, both verbal and nonverbal that potentially provokes a smile and laughter of the audience (Rustono, 1998). It serves as a means of social protest, educational means, means of entertainment and media to improve morals or moral (Danandjaja, 2002). Meanwhile, humour found in Banjar madihin art is related to pragmatics since there found violations of cooperative principle introduced by Grice that consists of four basic maxims as follow: maxim of quantity, maxim of quality, maxim of relevance, and maxim of implementation or maxim of manner (Rustono, 1998, Yule, 2006, Wijana and Rohmadi, 2011, Saghebi and Sobhani, 2014).

The development of madihin art is not as rapid as before due to the laxity of community traditions and attitudes of public indifference, especially the younger generation of Banjar madihin art. On the one hand, in the southern region of Borneo, especially in Banjarmasin, madihin art is used by madihin artists as an efficient medium to express thoughts and ideas on political, social and cultural issues by humming through humour. That is why it is very interesting to investigate, especially on its violations of cooperative principle. This research needs to be done because there is no 
previous research concerning about the violations of cooperative principle in Banjar madihin art which is realized as the creativity of humour. Meanwhile, the previous studies found only include 'Characteristics Studies, Staging Structure, Pemadihinan Creativity, Development and its follow up in South Kalimantan' (Rafiek, 2016) as well as religious values in madihin art (Leha, 2018). Regarding the previous explanation, the purpose of this study was to find any violations of cooperative principle as a means of creativity of humour in the Banjar madihin art. In addition, this study gives benefit to introduce local culture of Banjar area and expected to be a space for the existence of Banjar madihin art.

\section{Method}

Qualitative descriptive method was used in this study to describe the violations of cooperative principle in Banjar madihin art. The data consisted of 10 video recordings of this art performance. They were randomly downloaded from YouTube website and differed in terms of both date and location of performances since February 2017 to December 2017. The data of those 10 videos were collected by the methods of recording, relating and note-taking. Since the data of the videos were in form of spoken text, they were transcribed into the written one. The transcription results were identified, classified, categorized, and the analyzed using normative method. Meanwhile, normative method is a data matching method based on the criteria of cooperative principle. Then, the next stage was data presentation and conclusions drawing.

\section{Results and Discussion}

The violation of the cooperative principle is a condition in which speaker deliberately does not meet or obey the four conversation maxims to obtain the implicature effect in the speech and has a specific purpose such as to entertain, create funny talks, make a joke and others. The speaker violates the maxim when he / she knows that the listener will not know the truth and only understands the words surface meaning alone. In line with this, researches related to the cooperative principle and violations of conversational maxims of Grice (1975) have been conducted in various contexts. The studies included: analysis of ad languages (Pop, 2010, Liu, 2012), analysis of maxims adjustments in teaching writing (White, 2001), analysis of maxim implications during real time conversations (Sedivy, 2007), investigation of some conversational maxims violations in the Desperate Housewives TV series (Tupan and Natalia, 2008), analysis of four maxims in psychological counselling (Jia, 2008), analysis of maxim application for political interviews (Al-Hamadi and Muhammed, 2009), and analysis of deep conversational maxims film (Khosravizadeh Sadehvandi, 2011) and an analysis of the implementation of the cooperative principle in Indonesian native speakers (Herawati, 2013), pragmatic analysis of the use of presuppositions and implicatures as a fundamental resource in the film 'Woody Allen's Anything Else' (Alvaro, 2011 ), analysis of the violations of cooperative principle maxims in Japanese children and adults aged 4 to 6 years (Okanda et al, 2015), analysis of English humour based on the types of ambiguity, namely syntactic, semantic, lexical, and structural, the violations of maxims of manner and maxim of relevance (Taghiyev, 2017).

Based on the analysis, the researchers found some violations of the cooperative principle and conversation maxims. The violations occurred in the maxim of quantity, maxim of quality, maxim of relevance and maxim of manner. These maxims violations were committed by speakers or madihin artists in order to create humour or creativity of humour. The results of the findings are shown in Table 1.

Table 1. The Results of the Violations of Cooperative Principle in Banjar Madihin Art

\begin{tabular}{|c|c|c|c|}
\hline No & Maxims & $\begin{array}{l}\text { Number of } \\
\text { Violations }\end{array}$ & $(\%)$ \\
\hline 1 & Quantity & 6 & 17 \\
\hline 2 & Quality & 8 & 23 \\
\hline 3 & Relevance & 11 & 31 \\
\hline 4 & Manner & 10 & 29 \\
\hline \multicolumn{4}{|c|}{ Total } \\
\hline
\end{tabular}

Table 1 shows that the most violations found in madihin art was the violation of the maxim of relevance $(31 \%)$. It was because the speakers often provided information which was deviated from the topic discussed, 
irrelevant, and talked with jokes and excessive exchanges. The next maxim which had many violations was the maxim of manner as much as $29 \%$ data. This was because the speakers in the performance of Banjar madihin art talked something unclearly, having multiple interpretation and incoherent, so this is what made maxim violations occurred a lot. The next rank of maxim violation was obtained by maxim of quality violations of $23 \%$. This happened because speakers said things which were not true. Every participant of the conversation said something that did not have sufficient evidence. This was what caused this maxim of quality violation. At last, the least maxim violation came from maxim of quantity $(17 \%)$. Speakers (pemadihinan) contributed as much or as needed by the interlocutors, so that the violation of this maxim appeared to be the least among all.

These results are similar to the results of Rizkie's study (2013), which said that the violation of the cooperative principle in the use of good and correct language is very irrelevant because it can interfere in the communication process. In certain situations, the violation of the cooperative principle can occur. It is so functional as it is meant to entertain the audience with a humorous effect so as to provoke them to laugh or smile. Here are some examples of the analysis of the violations of cooperative principle in Banjar madihin art.

\section{Violation of Cooperative Principles}

The violation of cooperative principle in this study is showed in Table 1, covering 6 violations of maxim of quantity (17\%), 8 maxim of quality violations (23\%), 11 maxim of relevance violations (31\%) and 10 maxim of manner violation (29\%). All the maxims violated by the speakers or artists of madihin were aimed at entertaining the madihin lovers. Besides, the violation of cooperative principle is a condition in which speakers intentionally do not meet or obey the four sub-maxims (Zebua et al, 2017). In Banjar madihin art, the violations cooperative principle were in the form of maxim of quantity violation, maxim of quality violation, maxim of relevance violation, and violation of maxim of manner. Further, the violation of each maxim is described as follows:

\section{Maxim of Quantity Violation}

In this study, there found 6 violations of maxim of quantity (17\%) occurred in Banjar madihin art. This happened because the speakers (pemadihinan) named John Tralala provided excessive information. On the other hand, maxim of quantity requires the speaker to contribute sufficiently or as much as needed by the interlocutor. That is, the speaker must provide information in accordance with the needs of his opponent, no less and no more (Wijana and Rohmadi, 2011). This maxim requires the speaker to provide the information required by the speaker himself and not provide incomplete information (Kamariah, 2015). In essence, the maxim of quantity is violated when a speaker provides more or less information than is needed (Alduais, 2012). In the Banjar madihin art, the maxim of quantity violations were realized through the portion of information provided which was no longer as informative as it needed and exceeded or less than what was needed. Accordingly, the realization of maxim of quantity violations done by madihin artist named John Tralala appeared in the following excerpt:

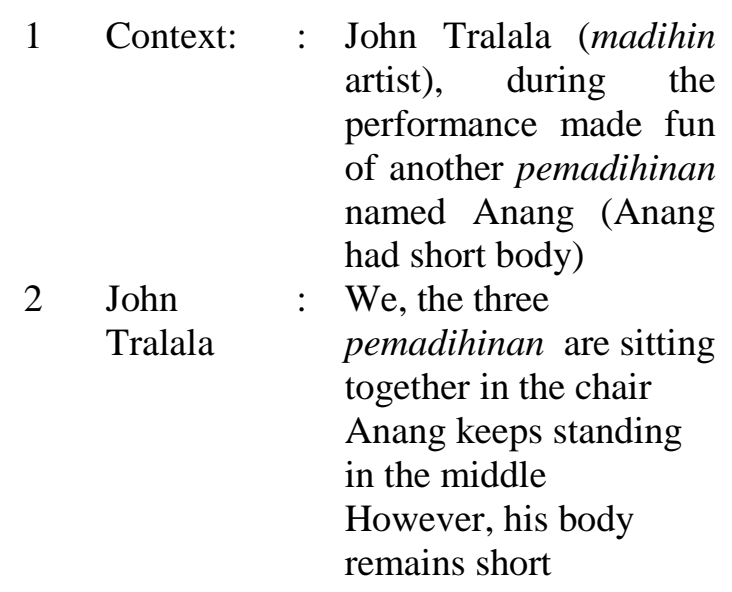

The madihin artist, John Tralala's play on data (1) showed excessive information and the violation of maxim of quantity appeared in the use of the sentence ' Anang keeps standing in the middle' which was more succinct and did not deviate from the truth value and for the interlocutor, it was more easily understood. Meanwhile, in the sentence 'his body remains short' explained obvious things, however, added to longwinded conversations. As a result, the phrase 'his body remains short' caused maximal of quantity violation. This maxim violation 
contrasted with the basic understanding of the quantity maxim. Such event raised the emphasis of Tralala's joke on Anang's abnormal physical condition of most people, namely 'short body' which further triggered laugh and humour in Banjar madihin art performance.

\section{Maximum of Quality Violation}

In Banjar madihin art performances, there found 8 maxim of quality violations $(23 \%)$. This violations were caused by the utterances spoken by the speaker (madihin artist) named John Tralala to Anang not in accordance with the reality and not in accordance with the evidence. In line with this, maximum quality requires honest speakers by avoiding saying anything that he thinks have no evidence or something they do not believe (Mehawesh and Jaradat, 2015). A violation of the cooperative principle, especially the maxim of quality is the essence of the actual conversation (Al-Hamadi and Muhammed, 2009). Accordingly, the quality maxim violations done by the speakers were caused by the need of causing the effect of humour. Further, this maxim violation were deliberate to bring up conversation implicatures, while some even meant to mock others. These violations caused a speaker to convey something unreal, false and not factual. For more, the realization of maxim of quality violations done by John Tralala was showed in the following excerpt:

(2) Context: : John Tralala mocked Anang by humiliating him

$\begin{array}{ll}\text { John } & : \text { Maybe Mr. Ciyut would } \\ \text { Tralala } & \text { like to accept me } \\ & \text { To become a coal boss } \\ & \text { in Binuang Subdistrict } \\ & \text { The Anang is indeed } \\ & \text { great } \\ & \text { Wearing a suit like a } \\ & \text { conglomerate } \\ & \text { Everywhere he boards } \\ \text { the plane }\end{array}$

The above excerpt (2) by John Tralala contained maxim of quality violation. It was because what was said by John Tralala to Anang was not based on the truth and not in accordance with the evidence. It appeared in the existence of the phrase 'wearing a suit like a conglomerate' 'everywhere he boards the plane' this speech contributed to violate the maxim of quality. John Tralala said that Anang was a conglomerate and boarded the plane as an initial speech reaction that said Anang was great to be a coal boss in Binuang Subdistrict. Such utterances did not match reality because Anang was just a madihin artist, not a conglomerate and everywhere he went, he did not get on a plane but motorcycles. In addition, in Banjar madihin art performance, the use of maxim of quality violation caused humour because the spoken words went against the facts. This violation was done John Tralala just as a mockery and ridicule to Anang with the intent to bring the effects of humour.

\section{Maxim of Relevance Violation}

Based on the results of analysis in this study, there found 11 violations of maxim of relevance $(31 \%)$. These violations occurred in madihin art because the meaning of the speech and the purpose of the speech were not relevant to the subsequent speech. Basically, maxim of relevance requires its speakers to make a contribution relevant to the subject of conversation (Wijana and Rohmadi, 2011). That is, a speech must be relevant to the content of the current conversation. The essence of all the maxims is the maxim of relevance really concerns the 'spacio-temporal' conversation. In this case, of course, the focus is on the "cooperative principle" because there is an adjustment to the speech situation "(Djajasudarma, 2012). One goal of violating maxim of relevance is to communicate the speaker's interest (Dornerus, 2005). In relation to this, the following data (3) reflect the speech of a madihin artist named John Tralala on the performance of Banjar madihin art that violated the maxim of relevance.

(3) Context: : John Tralala made fun of Anang by quipping his physical appearance

John : When seen from the Tralala front, he looks different Anang is as handsome as as keychain Please do not be picky in choosing a husband 
The above excerpt (3) of Banjar madihin art contains the violation of maxim of relevance. The clause 'when seen from the front, he looks different ' meaning and purpose were aimed at mocking the short physical appearance of Anang who was likened as a keychain. The meaning of the satire as well as the purpose of the speech were not relevant to the next speech that was 'Anang is as handsome as a keychain'. The violation of the relevance maxim continued with the following subsequent 'please do not be picky in choosing a husband'. Accordingly, these three utterances were irrelevant and not related to one another. However, the violation of this maxim of relevance apparently led to an oddity that triggers laugh and humour. This violation of maxim of relevance was done by the madihin artist in with the aim of creating humour and making the audiences laugh and get entertained.

\section{Maxim of Manner Violation}

The next maxim violation found in Banjar madihin art was the violation of maxim of manner. There were found 10 times maxim of manner violations (29\%). They were realized in the unclear and ambiguous speeches by the artists. Basically, in an interaction, maxim of manner is needed by speakers in order avoid ambiguity and unclarity (Tajabadi and Mehri, 2014). It demands the speakers to tell something clearly, no multiple interpretations and coherence. Also, this maxim requires every participant of the conversation speaks directly, not vague, no multiple interpretations, and not excessive (Wijana and Rohmadi, 2011). It is closely related to some obstacles in language use (Kamariah, 2015). This maxim is violated by raising the vagueness of what is being said. Again, it occurs when a speaker deliberately does not obey the maxim by no means of being brief, using language which is unclear, obscure, or ambiguous (Andresen, 2013). In relation to this, the artist of madihin art, John Tralala violated the maxim of manner in the following way:

(4) Context: : John Tralala described
the condition of
newlyweds in the
morning

$$
\begin{aligned}
& \text { John : The couple's hair is } \\
& \text { Tralala already wet in the } \\
& \text { morning } \\
& \text { If you don't believe it, } \\
& \text { ask Mr. Ciyut }
\end{aligned}
$$

In data (4) madihin artist, John Madal Tralala made a maxim of manner violation by saying 'the couple's hair is already wet in the morning'. The meaning of 'wet hair' in this utterance is unclear and ambiguous. The audiences would not know whether the wet hair is caused by raindrops or after-bathing effect.

These violations were done by Anang as the creativity of humour and aimed at entertaining the audiences so that later they would laugh. Furthermore, in this study, all violations of the cooperative principle were found and covered maxim of quantity, maxim of quality, maxim of relevance and maxim of manner. These all were caused by the irrelevant and unsuitable speeches on the topic being talked. They were unclear, disorderly and ambiguous. Therefore, this study is useful to introduce the local culture of Banjar area and expected to be a space for the existence of Banjar madihin art.

\section{Conclusion}

The violations of cooperative principle as a means of creativity of humour were found in Banjar madihin art. Those violations occurred against all maxims of cooperative principle. Of the many violations that occurred, it was found that the most occurred maxim violation went to maxim of relevance, followed maxim of manner, maxim of quality, and maxim of quantity, respectively. This confirms that the artists' speeches in Banjar madihin art are spoken irrelevantly or incompatible with the matter discussed, not brief, vague, disorderly and ambiguous.

\section{References}

Alduais, A. M, 2012. Conversational implicature (Flouting the maxims): applying conversational maxims on examples taken from non-standard arabic language, yemeni dialect, an idiolect spoken at IBB city. Journal of sociological research, 3(2), 376-387.

Al-Hamadi, H. M., \& Muhammed, B. J, 2009. Pragmatics: Grice's 
conversational maxims violations in the responses of some western politicians. Journal of the College of Arts, 50, 1-23.

Alvaro, N. R, 2011. The Role of Conversational Maxims, Implicature and Presupposition in the Creation of Humour: An Analysis of Woody Allen's Anything Else. Unpublished Master's Dissertation, Department of English Philology, UCM, 15, 2013.

Andresen, N, 2013. Flouting the maxims in comedy: An analysis of flouting in the comedy series community. Accessed on $17^{\text {th }}$ of February 2018. www.divaportal.org/smash/get/diva2:704301/fullte xt01.pdf

Djajasudarma, F, 2012. Wacana dan Pragmatik. Bandung: PT Refika Aditama. Page: 92

Dornerus, E, 2005. Breaking maxims in conversation a comparative study of how scriptwriters break maxims. In Desperate housewives and that 70's show. Retrieved on February $16^{\text {th }}$ 2018, from http://www.kau. divaportal.orgsmash-getdiva.pdf.

Faridah, Siti. 2017. Humour Dalam Sastra Lisan Madihin Banjar. Yogykarta: Penerbit K-Media. Page: 12

Herawati, Agnes. 2013. The Cooperative Principle: Is Grice's Theory Suitable To Indonesia Language Culture. Jurnal Lingua Cultura. Vol 7 (1). Pp 43-48.

Jia, L. I. (2008). The Violation of Cooperative Principle and the Four Maxims in Psychological Consulting. Canadian Social Science, 4(3), 87.

Kamariah. 2015. Pelanggaran Prinsip Kerjasama dan Prinsip Kesantunan Serta Implikaturnya dalam Novel Komedi Manusia Setengah Salmon Karya Raditya Dika (Violation of Coversation Principle and Modesty Principle and Implicature in the Novel Comedy of Setengah Salmon. Jurnal Bahasa, Sastra dan Pengajarannya (JBSP),5(2) 158178.

Khosravizadeh, $\mathrm{P}$ and Sadehvandi, N, 2011. Some Instances of Violation and Flouting of the Maxim of Quantity by the Main Characters (Barry \& Tim) in dinner for schmucks. In International
Conference on Languages, Literature and Linguistics. $P$ (pp. 122-127).

Leha, N, 2018. Kajian Nilai Religius pada Madihin Karya John Tralala. In Prosiding Seminar Nasional Bahasa dan Sastra Indonesia (SENASBASA) (Vol. 1, No. 1).

Liu, F, 2012. A Study of Principle of Conversation in Advertising Language. Theory and Practice in Language Studies, 2(12), 2619-2623

Mehawesh, M. I \& Jaradat, A. A, 2015. Inshallah: Extensive Flouting of Grice's Maxim of Quality. Asian Social Science, 11(4).

Okanda, M., Asada, K., Moriguchi, Y., \& Itakura, S. (2015). Understanding violations of Gricean maxims in preschoolers and adults. Front. Psychol. 6: 901. doi: 10.3389/fpsyg.

Pop, A, 2010. Implicatures derived through maxim flouting in print advertising: a contrastive empirical approach. Toronto Working Papers in Linguistics (TWPL), Volume 3.

Rafiek, M, 2016. Pantun Madihin: Kajian Ciri, Struktur Pementasan, Kreartiviti Pemadihinan, Pembangunan, dan Pembinaannya di Kalimantan Selatan. Jurnal Pendidikan Bahasa Melayu, 2(2), 104-114.

Rizkie, I. H, 2013. Pelanggaran Prinsip Kerja Sama dan Implikatur Wacana Humour dalam Rubrik "Mesem" Surat Kabar Harian Warta Jateng (Doctoral dissertation, Universitas Muhammadiyah Surakarta).

Rustono, 1998. Implikatur Percakapan sebagai Penunjang Pengungkapan Humour di dalam Wacana Humour Verbal Lisan Berbahasa Indonesia. Dissertation of Universitas Indonesia, Jakarta.

Sedivy, Julie. 2007. Implicature During Real Time Conversation: A View from Language Processing Research. May 2007 Philosophy Compass 2(3):475-496

Sobhani, Arezou and Ali Saghebi. 2014. The Violation of Cooperative Principles Four Maxims in Iranian Psychological Consultation. Journal of Scientific Research. vol 4. (2). pp. 91-99.

Taghiyev, Ilham, 2017. Violation of Grice's Maxims and Ambiguity in English Linguistic Jokes. 4th International 
Conference on Education and Social Sciences.

Tajabadi, A., Dowlatabadi, H., \& Mehri, E, 2014. Grice's Cooperative Maxims in Oral Arguments: The Case of Dispute Settlement Councils in Iran. ProcediaSocial and Behavioral Sciences, 98, 1859-1865

Tupan, A. H., and Natalia H. 2008. The multiple violations of conventional maxims in lying done by the characters in some episodes of Desperate Housewives. Journal of Pragmatics, (1) 63-78.

White, R. 2001. Adapting Grice's maxims in the teaching of writing. ELT Journal, 55(1), 62-69.
Wijana, I Dewa Putu dan Muhammad Rohmadi. 2011. Analisis Wacana Pragmatik: Kajian Teori dan Analisis. Surakarta: Yuma Pustaka. Hal:43-52

Yulianto, A, 2015. Revitalisasi Kesenian Lamut di Kalimantan Selatan. Naditira Widya, 9(2), 135-146.

Yule, G. (2006). Pragmatik (Translated edition by Indah Fajar Wahyuni dan Rombe Mustajab). Yogyakarta: Pustaka Pelajar.

Zebua, E., Rukmini, D., \& Saleh, M. 2017. The Violation and Flouting of Cooperative Principles in the Ellen Degeneres Talk Show. Language Circle: Journal of Language and Literature, 12(1), 103-113. 